\title{
VARIABEL-VARIABEL YANG MEMENGARUHI WAKTU HINGGA SESEORANG MENGGUNAKAN NARKOBA PERTAMA KALI MENGGUNAKAN ANALISIS SURVIVAL*
}

\author{
Widya Larasati ${ }^{1 \ddagger}$ and Mohammad Dokhi ${ }^{2}$ \\ 1Badan Pusat Statistik RI, Indonesia, widya.larasati@bps.go.id \\ 2Politeknik Statistika STIS, Indonesia, dokhi@stis.ac.id \\ fcorresponding author
}

Indonesian Journal of Statistics and Its Applications (eISSN:2599-0802)

Vol 4 No 1 (2020), 359 - 373

Copyright (C) 2020 Widya Larasati and Mohammad Dokhi. This is an open-access article distributed under the Creative Commons Attribution License, which permits unrestricted use, distribution, and reproduction in any medium, provided the original work is properly cited.

\begin{abstract}
Indonesia is currently in a state of emergency of drugs because of its increasing abuse rate and its spread is widespread not only in big cities. The average of first drug use is in adolescence. This study aims to determine the variables that influence the time for someone to use drugs for the first time and the acceleration factor. The data analyzed by using Survival Analysis with the frailty variable is secondary data from BNN and Puslitkes UI survey. The result is, the average of first drug use in eight towns/districts of research locus was 18-year. Smoking, alcohol consumption, the environment, and gender are significant variables that influence the first drug use. A person who has smoked, use alcohol, lived in a drug-exposed environment, and male sex will have a resilient time not to use drugs faster with the acceleration factor of each variable are $0.3184 ; 0.3985 ; 0.3501$; and 0.6773 . The results conclude that regulations on cigarettes and alcohol need to be revisited since both influence drug initiation. In addition, prevention programs need to focus more on adolescents and young children so that they have strong self-defense from the influence of a drug-exposed environment.
\end{abstract}

Keywords: alcohol, drugs, environment, frailty, smoking, survival analysis.

\section{Pendahuluan}

Penyalahgunaan narkoba sampai saat ini masih manjadi masalah yang krusial secara global. Di seluruh dunia, diperkirakan satu dari dua puluh orang dewasa atau seperempat juta orang berusia 15-64 tahun setidaknya menggunakan satu narkoba

\footnotetext{
* Received Des 2019; Accepted Jul 2020; Published online on Jul 2020
} 
pada tahun 2014. Peningkatan prevalensi pengguna narkoba sebasar 0,6 persen terjadi pada periode tahun 2008-2014 (UNODC, 2016). Menurut BNN (2015), Indonesia menempati peringkat tertinggi dalam hal transaksi narkoba jika dibandingkan negara-negara lain yang menjadi anggota ASEAN (Prayoga, 2015). Pada awalnya, Indonesia hanya menjadi tempat transit peredaran narkoba. Akan tetapi, saat ini berubah menjadi negara tujuan perdagangan narkoba. Oleh karena itu, pemerintah Indonesia telah memberlakukan situasi darurat narkoba untuk memutus mata rantai peredarannya (Galih, 2015).

Jumlah tersangka maupun kasus tindak pidana narkoba meningkat drastis pada tahun 2013 jika dibandingkan tahun sebelumnya yaitu sebanyak 35.436 kasus serta 43.767 tersangka (BNN, 2015). Selain itu, diperkirakan jumlah penyalahguna narkoba sekitar 3,1-3,6 juta orang atau setara dengan 1,9 persen dari populasi penduduk berusia 10-59 tahun pada tahun 2008 (BNN, 2009). Kasus ini meningkat pada tahun 2014 yang diperkirakan jumlah penyalahguna narkoba sebanyak 3,8-4,1 juta orang atau sekitar 2,25 persen. Hal ini mengindikasikan peredaran narkoba semakin marak (BNN, 2015). Disamping bertambahnya jumlah pengguna narkoba, masalah yang tidak kalah penting adalah tidak ada satu wilayah pun di Indonesia yang luput dari bahaya penyalahgunaan narkoba.

Kemajuan bidang teknologi informasi dan transportasi menjadi salah satunya sebabnya, sehingga peredaran segala jenis narkoba menjadi semakin mudah. Menurut BNN, besaran prevalensi penyalahguna narkoba antara kabupaten dan kota pada tahun 2015 semakin mengecil dan relatif sama besar dibandingkan tahun sebelumnya. Hal ini dapat menjadi indikasi awal dari keadaan penyebaran narkoba yang telah semakin meluas ke berbagai wilayah Indonesia tidak lagi hanya pada kotakota besar (BNN, 2016a).

Penggunaan narkoba yang pertama kali rata-rata terjadi pada usia yang masih dini yaitu usia remaja. Pada survei yang dilakukan BNN dan Puslitkes UI tahun 2015, rata-rata usia pertama kali menggunakan narkoba di Indonesia adalah 19 tahun dengan rentang terendah adalah usia 12 tahun (BNN, 2016b). Hal itu berarti, anak yang masih duduk di bangku sekolah dasar sudah mendapat akses dan menggunakan narkoba. Di sisi lain, usia 19 tahun merupakan usia disaat seseorang mulai bersosialisasi ke lingkungan yang lebih heterogen.

Kebanyakan dari mereka tidak tinggal dengan keluarga lagi atau merantau baik karena alasan melanjutkan pendidikan ke perguruan tinggi maupun untuk bekerja sehingga mereka rentan terpapar bahaya penyalahgunaan narkoba. Seseorang yang menggunakan narkoba pada usia dini akan meningkatkan risiko mereka pada dampak negatif yang ditimbulkan oleh narkoba pada masa yang akan dating (Knight et al., 2010). Diantara mereka yang menggunakan narkoba, alasan pertama kali pakai narkoba yang paling banyak dikemukakan adalah keinginan untuk mencoba (BNN, 2016b).

Pemerintah telah mempunyai program untuk menangani permasalahan terkait narkoba yang disebut Kebijakan dan Strategi Nasional Bidang Pencegahan dan Pemberantasan Penyalahgunaan dan Peredaran Gelap Narkoba (Jakstranas P4GN) dengan periode aktif tahun 2011-2015. Program P4GN ini mempunyai tujuan untuk mewujudkan "Indonesia Bebas Narkoba Tahun 2015". Salah satu target yang berhasil dicapai oleh program ini adalah menahan laju penyalahgunaan narkoba di bawah 2,8 
persen di akhir tahun 2015 (prevalensi tahun 2015 sebesar 2,2 persen). Akan tetapi, sasaran strategis yang berkaitan dengan kegiatan pencegahan penyalahgunaan narkoba yaitu meningkatkan kesadaran, partisipasi, dan kemandirian masyarakat dalam upaya pencegahan penyalahgunaan dan peredaran gelap narkoba banyak yang belum tercapai. Selain itu, meskipun berhasil mecapai target dalam menahan laju penyalahgunaan narkoba, pada saat yang bersamaan pemerintah pun mengumumkan situasi darurat narkoba bagi Indonesia. Hal ini menunjukkan bahwa permasalahan narkoba yang dihadapi Indonesia bukanlah persoalan yang sederhana lagi (BNN, 2016a).

Penelitian tentang variabel-variabel yang memengaruhi waktu hingga seseorang menggunakan narkoba pertama kali perlu dilakukan karena kejadian pertama kali menggunakan narkoba adalah tahap paling dini yang dilalui seorang pengguna sebelum akhirnya sampai pada titik yang paling parah yaitu menjadi pecandu narkoba. Selain itu, perilaku inisiasi atau penggunaan narkoba yang pertama kali memberikan informasi yang dapat digunakan dalam penilaian efektivitas program pencegahan saat ini dan penentuan fokus kebijakan diwaktu yang akan dating (Farhadinasab et al., 2008). Penelitian ini bertujuan untuk mengetahui gambaran umum pengguna narkoba dan meneliti variabel-variabel yang memengaruhi waktu hingga seseorang menggunakan narkoba pertama kali beserta faktor percepatannya di Kota Jakarta Pusat, Jakarta Selatan, Yogyakarta, Banda Aceh, Jayapura, dan Medan, serta Kabupaten Jayapura dan Deli Serdang tahun 2015. Dalam penelitian ini hanya digunakan beberapa variabel penjelas karena keterbatasan pada kondisi data. Variabel-variabel tersebut adalah perilaku merokok, konsumsi minuman keras, dan lingkungan sebagai variabel exposure. Sedangkan variabel kontrolnya adalah jenis kelamin. Dasar pemilihan variabel penjelas yang digunakan adalah berdasarkan penelitian terkait.

Terdapat beberapa penelitian terdahulu yang relevan dengan penelitian ini. Salah satunya penelitian oleh Chen et al. (2016) yang berjudul "Current Patterns of Marijuana Use Initiation by Age among US Adolescent and Emerging Adults: Implications for Intervention" dengan tujuan meneliti risiko inisiasi penggunaan ganja di sepanjang rentang usia sejak lahir hingga remaja dan awal usia dewasa. Hasilnya menunjukkan bahwa risiko inisiasi penggunaan ganja meningkat secara bertahap sampai usia sebelas tahun.

Akan tetapi, kenaikannya semakin cepat dan membentuk puncak pertama pada usia 16 tahun. Kemudian, risikonya mengalami penurunan pada usia 17 tahun dan kembali meningkat drastis pada usia 18 tahun sehingga membentuk puncak kedua yang lebih tinggi dari puncak pertama. Responden dengan jenis kelamin laki-laki secara signifikan memiliki risiko lebih tinggi untuk melakukan inisiasi penggunaan narkoba dibandingkan perempuan.

Selanjutnya adalah penelitian oleh Nonnemaker et al. (2012) yang berjudul "Parent- Child Communication and Marijuana Initiation: Evidence Using DiscreteTime Survival Analysis". Hasilnya, komunikasi orang tua dan anak tentang narkoba (ganja) tidak terlalu bepengaruh pada pencegahan inisiasi penggunaan ganja. Akan tetapi, variabel pengaruh teman sebaya, perilaku merokok, konsumsi minuman keras, dan kejadian pernah ditawari ganja secara signifikan berhubungan dengan peningkatan risiko inisiasi penggunaan ganja. 
Selain itu, ada pula penelitian oleh Korhonen et al. (2008) yang berjudul "Role of Individual, Peer and Family Factor in the Use of Cannabis and Other Illicit Drugs: A Longitudinal Analysis among Finnish Adolescent Twins" yang bertujuan untuk menganalisis faktor yang memprediksi penggunaan ganja dan narkoba lain pada remaja kembar di Finlandia. Hasilnya, remaja yang merokok pada usia dini dan pernah minum minuman keras secara signifikan memengaruhi penggunaan narkoba dengan risiko masing-masing 25,9 dan 2,61. Selain itu, untuk faktor teman sebaya, jumlah teman yang merokok dan adanya teman yang menggunakan narkoba juga merupakan prediktor penggunaan narkoba dengan signifikansi tinggi (OR: 2,05 dan 2,75). Kemudian, dari sisi faktor keluarga, seseorang yang memiliki ayah sering mabuk- mabukan akan berisiko 3,41 lebih tinggi untuk menggunakan narkoba dibandingkan yang tidak memiliki.

Terdapat pula penelitian oleh Bar (2007) yang berjudul "Determinan Penyalahgunaan Narkoba pada Pekerja Pengunjung Tempat Hiburan" juga bertujuan untuk meneliti faktor-faktor yang berhubungan dengan penyalahgunaan narkoba pada pekerja memperoleh hasil bahwa variabel umur, pendidikan, perilaku merokok, ketaatan beragama dalam keluarga, pendapatan, hubungan interpersonal dalam keluarga dan status perkawinan signifikan berhubungan dengan penyalahgunaan narkoba. Pekerja yang merokok berisiko untuk menyalahgunakan narkoba tiga kali lebih besar daripada yang tidak merokok.

\section{Metodologi}

\subsection{Sumber Data}

Data yang digunakan dalam penelitian ini adalah data sekunder berupa data mentah (raw data) dari hasil Survei Prevalensi Penyalahgunaan Narkoba pada Kelompok Rumah Tangga di 20 Provinsi Tahun 2015. Survei ini dilakukan oleh Badan Narkotika Nasional (BNN) yang bekerja sama dengan Pusat Penelitian Kesehatan (Puslitkes) Universitas Indonesia pada tahun 2015. Tujuan dari survei ini adalah untuk mengetahui prevalensi dan faktor terkait pengetahuan, sikap, dan praktik penyalahgunaan narkoba dimasyarakat. Survei ini menggunakan pendekatan crosssectional dengan cakupan rumah tangga yang terdiri dari rumah tangga (biasa) dan rumah tangga khusus atau disebut juga rumah kos. Kriteria responden adalah mereka yang berusia 10-59 tahun. Pengumpulan data dilakukan dengan tiga cara, yaitu wawancara dengan kuesioner terstruktur, wawancara mendalam, dan diskusi kelompok terpimpin.

\subsection{Objek Penelitian}

Prosedur penyaringan objek penelitian dalam penelitian ini pertama mengelompokkan responden berusia 10-59 tahun ke dalam kategori mengalami kejadian atau tersensor berdasarkan status pernah pakai narkoba. Kedua, mengidentifikasi missing value dari data kemudian mengidentifikasi variabel respons baik untuk yang mengalami kejadian maupun tersensor. 


\subsection{Analisis Deskriptif}

Metode analisis yang digunakan adalah analisis deskriptif dan analisis inferensia. Analisis deskriptif digunakan untuk memberikan gambaran umum mengenai penggunaan narkoba di Kota Jakarta Pusat, Jakarta Selatan, Yogyakarta, Banda Aceh, Jayapura, dan Medan, serta Kabupaten Jayapura dan Deli Serdang tahun 2015.

Penyajian data dilakukan menggunakan tabel dan grafik. Selain itu, dalam penelitian ini juga dilakukan analisis tambahan menggunakan kurva Kaplan-Meier untuk melihat perbedaan ketahanan dari tiap-tiap kategori dalam variabel prediktor.

\subsection{Analisis Inferensia}

Analisis inferensia yang digunakan dalam penelitian ini adalah Analisis Ketahanan Hidup (Survival Analysis). Analisis ketahanan hidup digunakaan untuk membentuk suatu model yang dapat menjelaskan pengaruh dari variabel penjelas terhadap kejadian penggunaan narkoba pertama kali. Sebelum dibentuk model tersebut, terlebih dulu menentukan pendekatan yang akan digunakan yaitu pendekatan parametrik. Kemudian menentukan distribusi yang paling cocok untuk menggambarkan waktu ketahanan hidup. Pemilihan distribusi menggunakan nilai AIC. Pada penelitian ini, diperoleh distribusi yang paling cocok yaitu distribusi Weibull Gamma-Frailty, dengan pertimbangan nilai AIC yang kecil dan signifikansi dari variabel frailty.

\section{Hasil dan Pembahasan}

\subsection{Gambaran Umum Karakteristik Pengguna Narkoba di Delapan Kota/Kabupaten Tahun 2015}

Hasil pengolahan data dari delapan kota/kabupaten yang menjadi lokus dalam penelitian ini menunjukkan bahwa total responden berjumlah 2.686 responden. Dari keseluruhan responden tersebut, sebanyak 116 atau 4,32 persen pernah menggunakan narkoba minimal sekali seumur hidup seperti yang ditunjukkan pada Gambar 1.

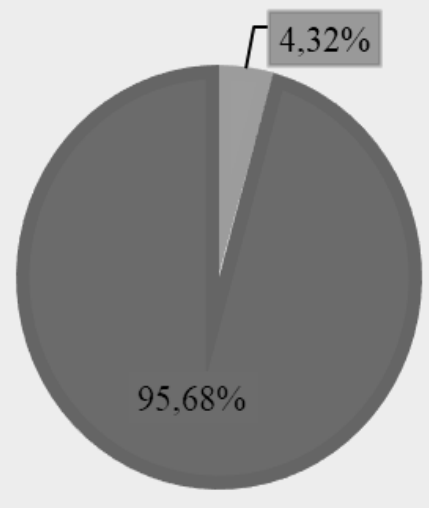

- Menggunakan narkoba

- Tidak menggunakan narkoba

Gambar 1: Persentase pengguna narkoba di delapan kota/kabupaten tahun 2015 Sumber: SPPN Kelompok Rumah Tangga di 20 Provinsi Tahun 2015 (diolah) 
Kota Jakarta Selatan merupakan kota dengan persentase pengguna narkoba tertinggi yaitu sebesar 8,1 persen. Sedangkan, persentase pengguna narkoba terendah terdapat di Kabupaten Deli Serdang. Lebih jelasnya dapat dilihat pada Gambar 2. Para pengguna narkoba menunjukkan variasi dari sisi umur pertama kali menggunakan narkoba. Rata-rata umur menggunakan narkoba pertama kali secara keseluruhan adalah 18 tahun seperti yang terlihat pada Tabel 1.

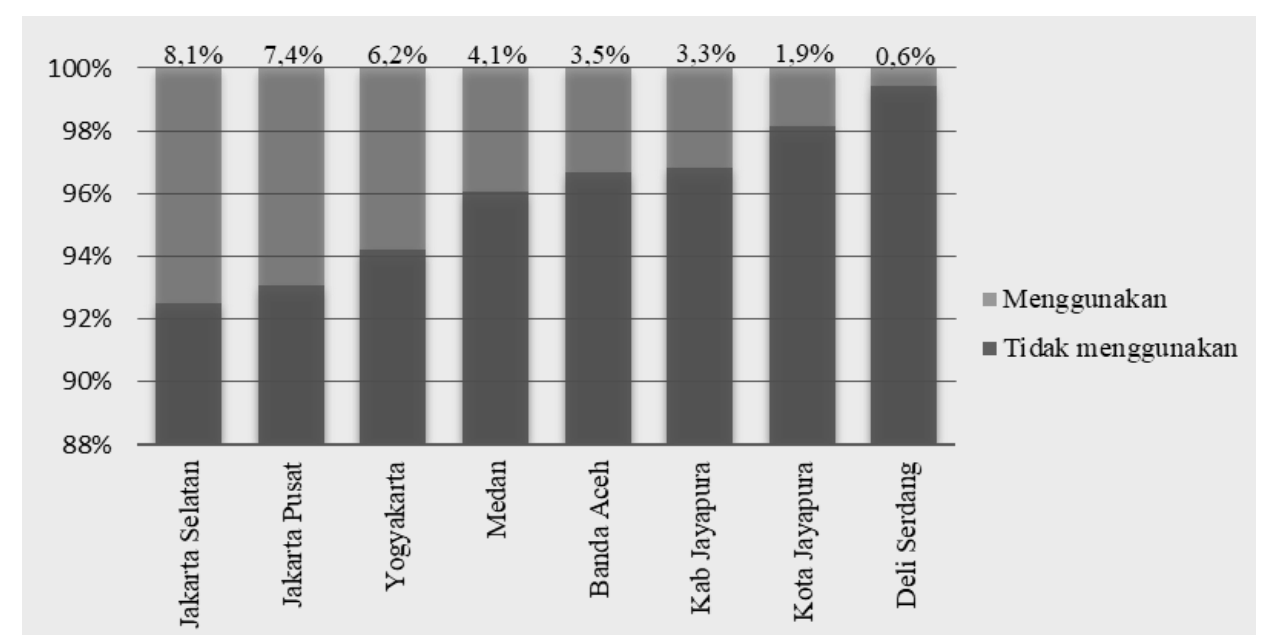

Gambar 2: Persentase pengguna narkoba menurut provinsi tahun 2015. Sumber: SPPN Kelompok Rumah Tangga di 20 Provinsi Tahun 2015 (diolah)

Tabel 1: Rata-rata umur menggunakan narkoba pertama kali menurut wilayah.

\begin{tabular}{lc}
\hline \multicolumn{1}{c}{ Wilayah } & $\begin{array}{c}\text { Rata-rata Umur Menggunakan Narkoba } \\
\text { Pertama Kali (Tahun) }\end{array}$ \\
\hline Keseluruhan & 18 \\
Kota Banda Aceh & 17 \\
Kota Medan & 19 \\
Kota Jakarta Pusat & 16 \\
Kota Jakarta Selatan & 19 \\
Kota Yogyakarta & 18 \\
Kota Jayapura & 20 \\
Kabupaten Deli Serdang & 18 \\
Kabupaten Jayapura & 23 \\
\hline
\end{tabular}

Sumber: SPPN Kelompok Rumah Tangga di 20 Provinsi Tahun 2015 (diolah)

Jenis narkoba yang dikonsumsi oleh pengguna juga beragam. Akan tetapi, sebanyak 75,00 persen pengguna mengonsumsi jenis ganja pada saat pertama kali menggunakan narkoba. Data untuk jenis narkoba yang lain dapat dilihat pada Gambar 3. 


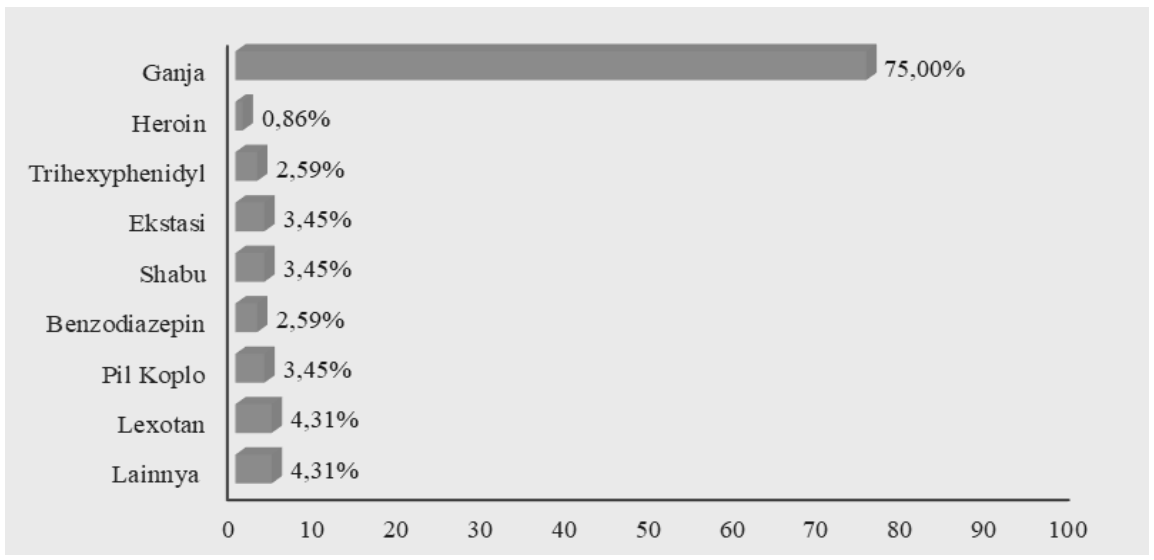

Gambar 3: Persentase jenis narkoba yang digunakan pertama kali Sumber: SPPN Kelompok Rumah Tangga di 20 Provinsi Tahun 2015 (diolah)

Sebanyak 95,69 persen pengguna narkoba mengaku mendapatkan narkoba dari temannya. Di sisi lain, alasan menggunakan narkoba pertama kali yang paling banyak dikemukakan adalah keinginan untuk mencoba. Seperti yang terlihat pada Gambar 4, sebanyak 65,52 persen pengguna beralasan ingin mencoba pada saat pertama kali menggunakan.

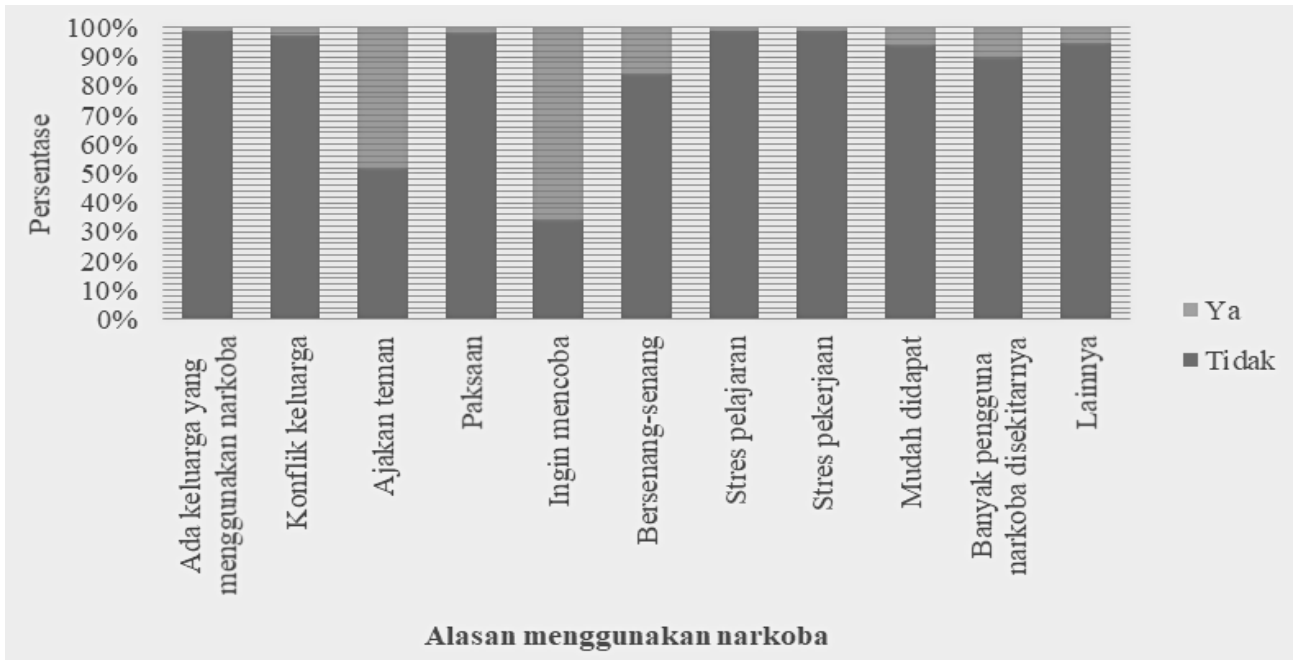

Gambar 4: Persentase alasan menggunakan narkoba pertama kali. Sumber: SPPN Kelompok Rumah Tangga di 20 Provinsi Tahun 2015 (diolah)

Persentase responden pengguna narkoba yang pernah merokok lebih besar dibandingkan dengan responden pengguna narkoba yang tidak pernah merokok seperti yang disajikan pada Gambar 5. Tingginya jumlah pengguna narkoba yang pernah merokok minimal sekali seumur hidup mereka mengindikasikan bahwa rokok memengaruhi penggunaan narkoba. Sering disebutkan bahwa rokok merupakan pintu gerbang menuju narkoba (Farhadinasab et al., 2008). Selain itu, dari Kurva Kaplan-Meier Gambar 6 terlihat bahwa terdapat perbedaan yang signifikan antara seseorang yang pernah merokok dan tidak pernah merokok. 


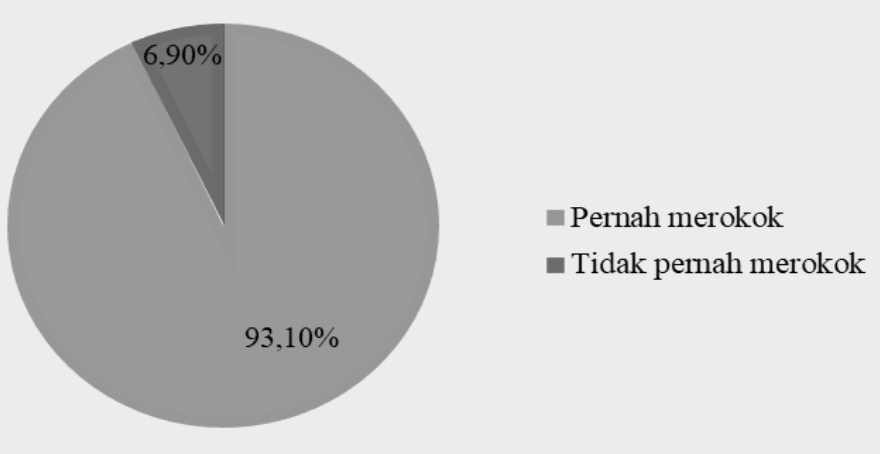

Gambar 5: Persentase pengguna narkoba menurut status merokok. Sumber: SPPN Kelompok Rumah Tangga di 20 Provinsi Tahun 2015 (diolah)

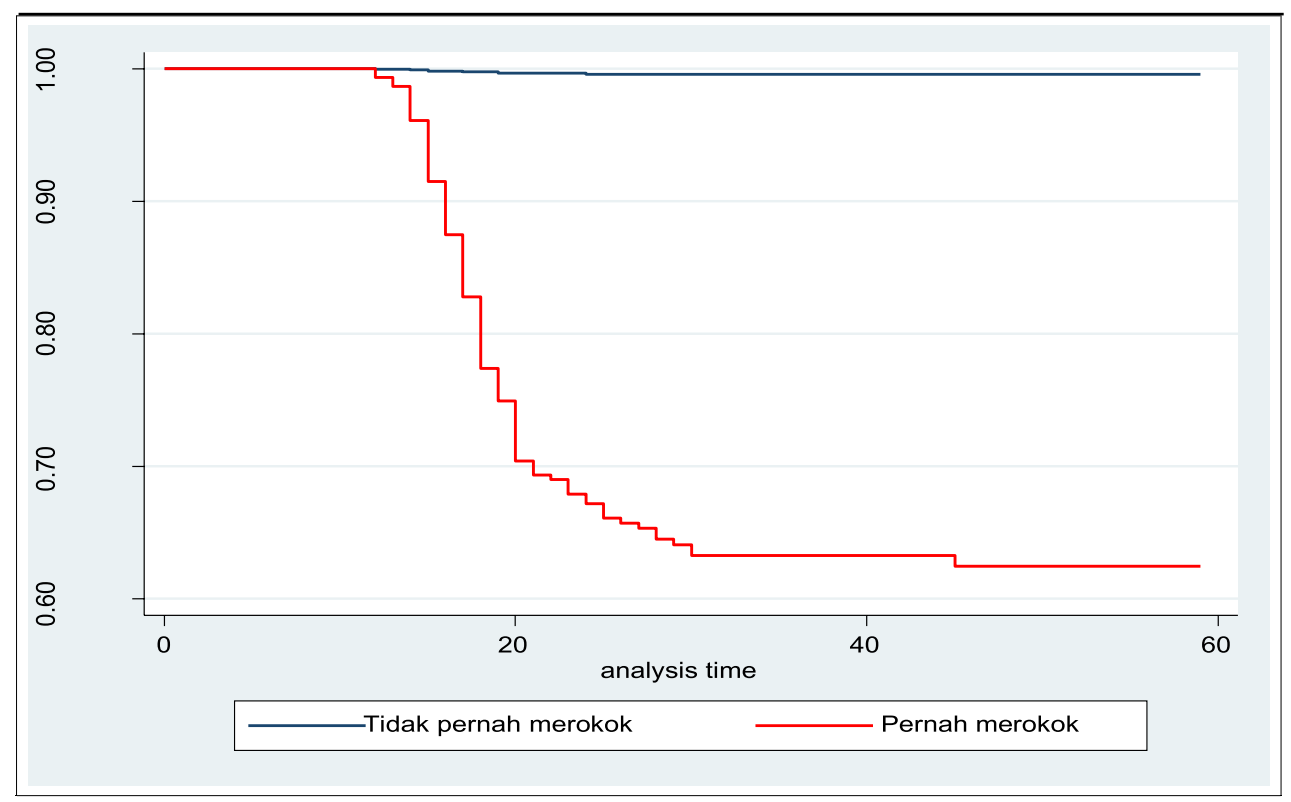

Gambar 6: Kurva fungsi ketahanan Kaplan-Meier untuk variabel merokok.

Sumber: SPPN Kelompok Rumah Tangga di 20 Provinsi Tahun 2015 (diolah)

Persentase responden pengguna narkoba yang pernah minum minuman keras lebih besar dibandingkan dengan responden pengguna narkoba yang tidak pernah minum minuman keras seperti yang terlihat dari Gambar 7. Seseorang yang sudah biasa menoleransi efek alkohol akan cenderung mencoba hal lain salah satunya menggunakan narkoba untuk mencari efek yang lebih kuat. Oleh karena itu, konsumsi minuman keras dapat menjadi jalan untuk penggunaan narkoba. Selain itu, dari Kurva Kaplan-Meier pada Gambar 8 menunjukkan bahwa terdapat perbedaan yang signifikan antara seseorang yang pernah mengonsumsi minuman keras dan seseorang yang tidak pernah mengonsumsi minuman keras. 


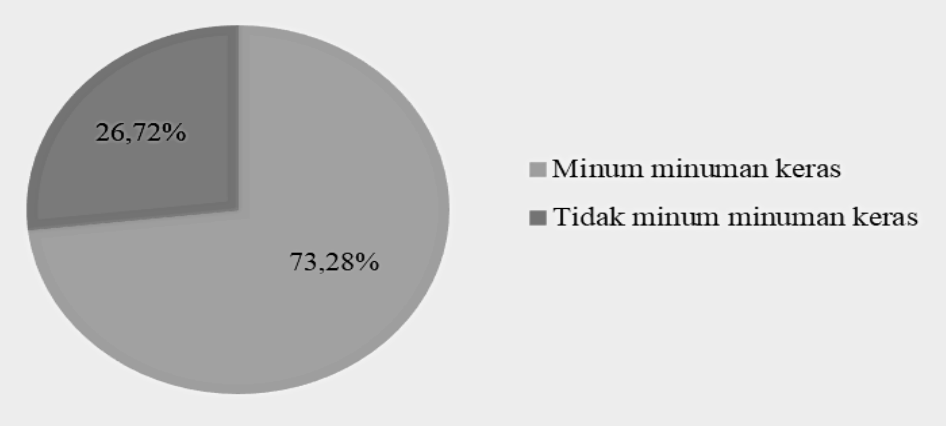

Gambar 7: Persentase pengguna narkoba menurut status konsumsi minuman keras. Sumber: SPPN Kelompok Rumah Tangga di 20 Provinsi Tahun 2015 (diolah)

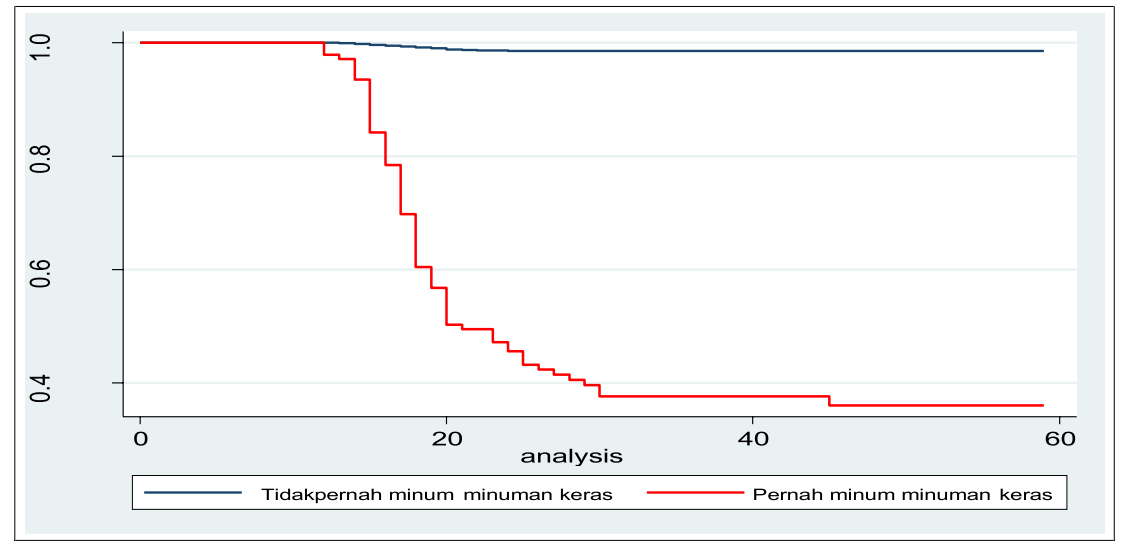

Gambar 8: Kurva fungsi ketahanan Kaplan-Meier untuk variabel konsumsi minuman keras.

Sumber: SPPN Kelompok Rumah Tangga di 20 Provinsi Tahun 2015 (diolah)

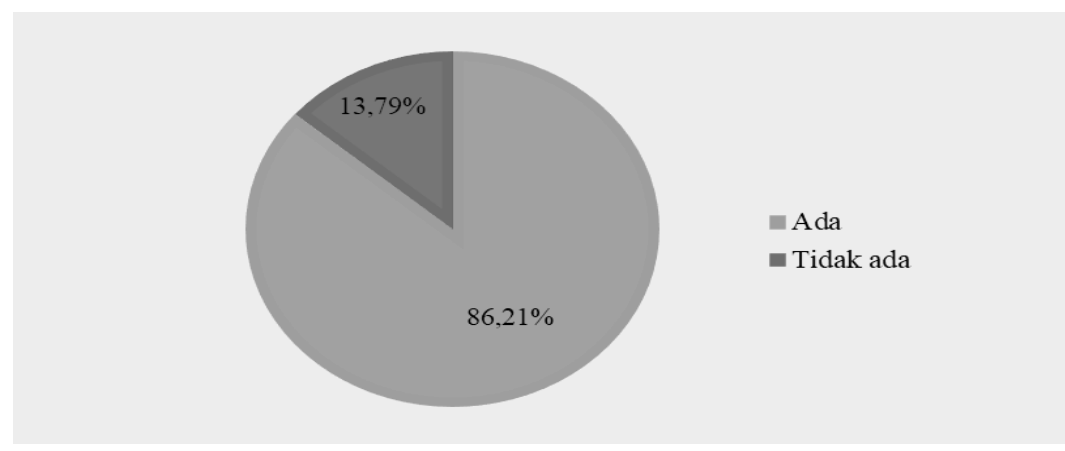

Gambar 9: Persentase pengguna narkoba menurut status keberadaan keluarga atau teman yang menggunakan narkoba.

Sumber: SPPN Kelompok Rumah Tangga di 20 Provinsi Tahun 2015 (diolah) 
Responden pengguna narkoba yang tinggal di lingkungan terpapar narkoba, ditandai dengan memiliki keluarga atau teman yang menggunakan narkoba lebih besar dibandingkan dengan responden pengguna narkoba yang tidak memiliki keluarga atau teman yang menggunakan narkoba seperti yang disajikan pada Gambar 9. Perilaku orang-orang disekitarnya seperti menggunakan narkoba dapat memengaruihi perilaku seseorang untuk menggunakannya juga. Selain itu, dari Kurva Kaplan-Meier Gambar 10 terlihat perbedaan signifikan antara seseorang yang memiliki keluarga atau teman yang juga menggunakan narkoba dan seseorang yang tidak memiliki.

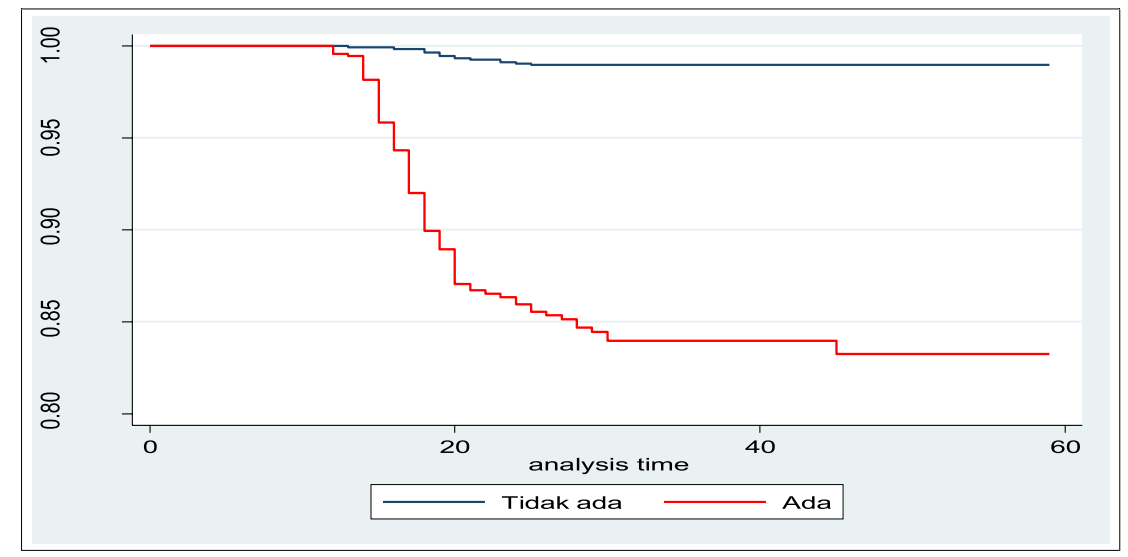

Gambar 10: Kurva fungsi ketahanan Kaplan-Meier untuk variabel lingkungan (keberadaan keluarga atau teman yang menggunakan narkoba).

Sumber: SPPN Kelompok Rumah Tangga di 20 Provinsi Tahun 2015 (diolah)

Persentase responden pengguna narkoba laki-laki lebih besar dibandingkan dengan responden pengguna narkoba perempuan seperti yang terlihat pada Gambar 11. Selain itu, dari Kurva Kaplan-Meier Gambar 12 terlihat perbedaan yang signifikan antara laki-laki dan perempuan dalam hal kecenderungan menggunakan narkoba.

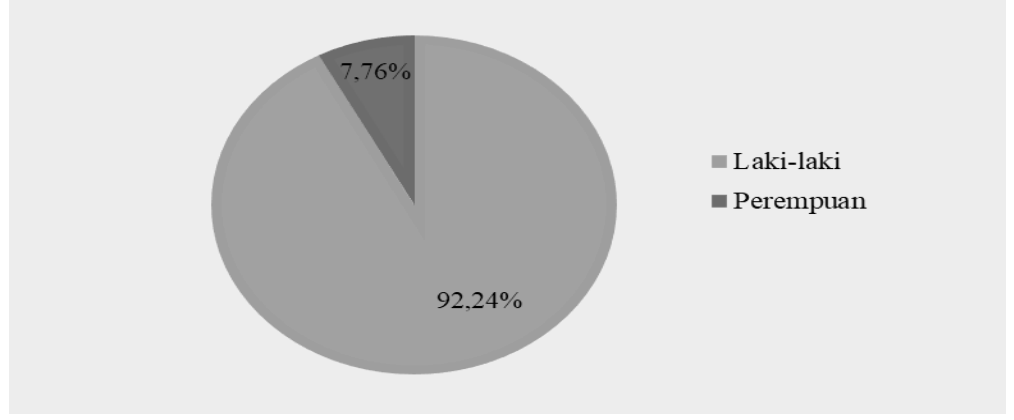

Gambar 11: Persentase pengguna narkoba menurut jenis kelamin. Sumber: SPPN Kelompok Rumah Tangga di 20 Provinsi Tahun 2015 (diolah) 


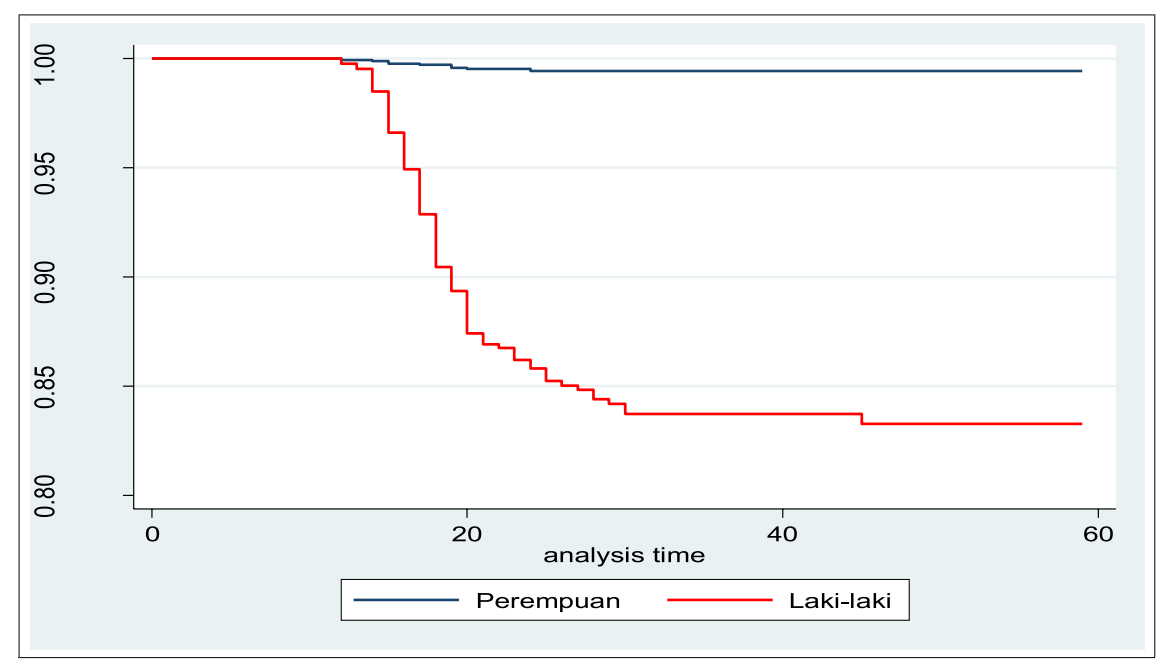

Gambar 12: Kurva fungsi ketahanan Kaplan-Meier untuk variabel jenis kelamin. Sumber: SPPN Kelompok Rumah Tangga di 20 Provinsi Tahun 2015 (diolah)

\subsection{Variabel yang Memengaruhi Seseorang Menggunakan Narkoba Pertama Kali}

Model yang digunakan dalam penelitian ini adalah Weibull Regression Gamma Frailty. Model tersebut dipilih dengan pertimbangan nilai AIC yang kecil dan variabel frailty yang memiliki pengaruh yang signifikan. Hasil pengujian simultan diperoleh nilai $\mathrm{Chi}$ Square hitung sebesar 483,22 dengan $p$-value 0,000 atau kurang dari $\alpha=0,05$ yang berarti tolak $\mathrm{H} 0$. Sehingga dapat disimpulkan bahwa minimal terdapat satu variabel penjelas yang memengaruhi umur pertama kali menggunakan narkoba. Selanjutnya dilakukan uji parsial untuk mengetahui variabel apa saja yang signifikan memengaruhi umur pertama kali menggunakan narkoba. Hasil pengolahan data mengunakan Survival Anaysis Weibull Regression Gamma Frailty disajikan pada Tabel 2.

Tabel 2: Nilai koefisien, estimasi faktor percepatan, standar eror $(\hat{\sigma}), Z$ hitung, signifikansi, dan 95\% Confidence Interval $\hat{\gamma}$ model Survival Weibull Regression Gamma Frailty.

\begin{tabular}{cccccccc}
\hline $\begin{array}{c}\text { Kode } \\
\text { Variabel }\end{array}$ & $\hat{a}$ & $\hat{y}$ & $S E(\hat{\alpha})$ & $Z(\hat{\alpha})$ & Sig & \multicolumn{2}{c}{ Cl 95\% untuk } \\
\hline rokok & $-1,1443$ & 0,318 & 0,2005 & $-5,71$ & 0,000 & 0.215 & 0.4718 \\
miras & $-0,9200$ & 0,398 & 0,1270 & $-7,24$ & 0,000 & 0.310 & 0.5111 \\
lingkungan & $-1,0495$ & 0,350 & 0,1387 & $-7,57$ & 0,000 & 0.266 & 0.4595 \\
JK & $-0,3896$ & 0,677 & 0,1756 & $-2,22$ & 0,027 & 0.480 & 0.9556 \\
cons & 6,4547 & 3 & 0,3293 & 19,60 & 0,000 & 1 & \\
& 2,6158 & & & & & & \\
& 1,0696 & & 0,4134 & & 0,000 & & \\
\hline
\end{tabular}

Sumber: SPPN Kelompok Rumah Tangga di 20 Provinsi Tahun 2015 (diolah) 
Dari Tabel 2 dapat diambil kesimpulan bahwa ketiga variabel yang menjadi exposure yaitu merokok, konsumsi minuman keras, dan lingkungan secara signifikan memengaruhi umur menggunakan narkoba pertama kali dengan taraf nyata 0,05. Selain itu, variabel jenis kelamin yang menjadi variabel kontrol pengaruhnya terhadap umur menggunakan narkoba pertama kali juga signifikan dalam taraf nyata 0,05.

Persamaan yang dapat dibentuk adalah sebagai berikut:

$$
\begin{aligned}
& \widehat{S}_{j}\left(t \mid z_{j}\right)=\left(\exp \left[-\lambda t^{2,6158}\right]\right)^{z_{j}} \\
& t=(-\ln (S(t)))^{1 / 2,6158} \frac{1}{\lambda^{1 / 2,6158}} \\
& \frac{1}{\lambda^{1 / 2 p_{2} 2_{2}}}=\exp [6,4547-1,1443 \text { rokok-0,9200 miras }-1,0495 \text { lingkungan- } 0,3896 \mathrm{JK}]
\end{aligned}
$$

dalam hal ini Z merupakan peubah acak frailty yang diasumsikan berdistribusi Gamma dengan rata- rata satu dan varians yang diestimasi dari data sebesar $\bar{\theta}=1,0696$. Nilai $\bar{\theta}$ yang lebih dari satu mengindikasikan bahwa variabel frailty signifikan dalam model. Hal ini diperkuat dengan hasil signifikansi yaitu sebesar 0,000. Artinya, terdapat variabel bebas yang diyakini memengaruhi umur menggunakan narkoba pertama kali yang tidak termasuk ke dalam model atau bahkan variabel tersebut tidak tercakup dalam survei.

\subsection{Nilai Faktor Percepatan Seseorang untuk Menggunakan Narkoba Pertama Kali}

Nilai faktor percepatan seseorang untuk menggunakan narkoba pertama kali adalah sebagai berikut:

1. Variabel merokok mempunyai faktor percepatan sebesar 0,3184 . Hasil tersebut menunjukkan bahwa, saat variabel lain konstan, survival time (waktu ketahanan untuk tidak menggunakan narkoba) seseorang yang pernah merokok akan berkurang sebesar 0,3184 kali dibandingkan yang tidak pernah merokok. Dengan kata lain, seseorang yang pernah merokok akan lebih cepat untuk menggunakan narkoba pertama kali dibandingkan yang tidak pernah merokok dengan faktor 0,3184 kali. Hasil ini sesuai dengan penelitian Farhadinasab et al. (2008), disebutkan bahwa setengah dari responden penelitian yang merupakan pengguna narkoba, mereka mengonsumsi rokok, minuman keras, dan ganja.

Lebih lanjut dijelaskan bahwa tembakau dan alkohol merupakan substansi yang paling umum sebagai gerbang menuju penggunaan ganja dan opium. Penelitian lain oleh Bar (2007) yang menganalisis penyalahgunaan narkoba pada pekerja pengunjung tempat hiburan mendapatkan hasil bahwa pekerja tempat hiburan yang merokok berisiko 3,10 kali lebih besar untuk menyalahgunakan narkoba kategori coba pakai dibandingkan pekerja yang tidak merokok. Selain itu, hasil yang sejalan juga ditunjukkan pada penelitian Korhonen et al. (2008) yang menunjukkan merokok signifikan memengaruhi penggunaan ganja dan obat-obatan terlarang lainnya dengan OR sebesar 25,9.

Risiko inisiasi narkoba (ganja) pada perokok akan meningkat seiring dengan peningkatan jumlah rokok yang dikonsumsi Mayet et al. (2012). Meskipun telah ada peraturan pemerintah mengenai larangan penjualan produk tembakau pada anak-anak (dibawah 18 tahun) dan ibu hamil, pada kenyataannya kedua 
kelompok tersebut tetap dapat dengan mudah mendapatkan rokok dari pedagang kaki lima, toko kelontong, dan minimarket semudah seperti membeli permen karena rokok juga dijual batangan (WHO, 2015).

2. Variabel konsumsi minuman keras memiliki faktor percepatan sebesar 0,3985. Hasil tersebut menunjukkan bahwa, saat variabel lain konstan, survival time (waktu ketahanan untuk tidak menggunakan narkoba) seseorang yang pernah minum minuman keras akan berkurang sebesar 0,3985 kali dibandingkan yang tidak pernah minum minuman keras. Dengan kata lain, seseorang yang pernah minum minuman keras akan lebih cepat untuk menggunakan narkoba pertama kali dibandingkan yang tidak pernah minum minuman keras dengan faktor 0,3985 kali.

Sama seperti merokok, minuman keras juga mempunyai peran dengan menjadi gerbang kecil pada penggunaan narkoba (Farhadinasab et al., 2008; Fergusson et al., 2008). Lebih lajut dijelaskan, bahwa penggunaan narkoba dimediasi oleh penggunaan minuman keras dalam rentang umur 16-25 tahun (Fergusson et al., 2008) . Seseorang yang mengonsumsi minuman keras memiliki risiko 2,61 kali lebih besar untuk menggunakan ganja dan obat terlarang lainnya (Korhonen et al., 2008).

3. Variabel lingkungan memiliki faktor percepatan sebesar 0,3501. Hasil tersebut menunjukkan bahwa, saat variabel lain konstan, survival time (waktu ketahanan untuk tidak menggunakan narkoba) seseorang yang tinggal di lingkungan yang terpapar narkoba, ditandai dengan adanya saudara atau teman yang menggunakan narkoba, akan berkurang sebesar 0,3501 kali dibandingkan yang tinggal di lingkungan yang tidak terpapar narkoba.

Dengan kata lain, seseorang yang mempunyai saudara atau teman yang menggunakan narkoba akan lebih cepat untuk menggunakan narkoba pertama kali dibandingkan yang tidak mempunyai saudara atau teman yang menggunakan narkoba dengan faktor 0,3501 kali. Lingkungan menyediakan pengalaman belajar yang membentuk atau mengubah pola kebiasaan seseorang. Lingkungan yang terpapar oleh narkoba, ditandai oleh keberadaan keluarga atau teman yang menggunakan narkoba disekitarnya, akan meningkatkan peluang seseorang untuk mulai menggunakan narkoba.

Hal ini diperkuat dengan penelitian (Korhonen et al., 2008) yang mendapatkan hasil bahwa saat seseorang memiliki kenalan yang juga menggunakan narkoba, maka ia akan berisiko 1,64 kali lebih tinggi untuk menggunakan ganja dan narkoba lain. Penelitian lain yang dilakukan (Farhadinasab et al., 2008) juga mendapatkan hasil bahwa diantara responden yang menggunakan narkoba setahun terakhir, penggunaan opium berhubungan secara signifikan dengan kepemilikan ibu yang merokok dan teman yang menggunakan narkoba. Lebih lanjut dijelaskan, bahwa secara keseluruhan mempunyai teman yang menggunakan narkoba berhubungan dengan penggunaan ganja, opium, dan ekstasi. Selain itu, hasil penelitian (Fergusson et al., 2008) juga menunjukkan bahwa mereka yang orang tuanya menggunakan narkoba minimal sekali, akan meningkatkan risiko untuk menggunakan narkoba juga di kemudian hari. 
4. Variabel jenis kelamin memeiliki faktor percepatan sebesar 0,6773. Hasil tersebut menunjukkan bahwa, saat variabel lain konstan, survival time (waktu ketahanan untuk tidak menggunakan narkoba) seorang laki-laki akan berkurang sebesar 0,6773 kali dibandingkan perempuan. Dengan kata lain, seorang lakilaki akan lebih cepat untuk menggunakan narkoba pertama kali dibandingkan perempuan dengan faktor 0,6773 kali.

Hasil tersebut sejalan dengan penelitian (Chen et al., 2016) yang menjelaskan bahwa responden dengan jenis kelamin laki-laki secara signifikan memiliki risiko lebih tinggi untuk melakukan inisiasi penggunaan narkoba dibandingkan perempuan. Selain itu, (Fergusson et al., 2008) juga memeperoleh hasil bahwa mereka yang berjenis kelamin laki-laki lebih berisiko untuk menggunakan narkoba dibandingkan perempuan. Diperkuat pula oleh penelitian Lamptey (2005) bahwa terdapat perbedaan signifikan antara laki-laki dan perempuan penyalahguna narkoba dan menjadi masalah besar pada remaja laki-laki.

\section{Simpulan}

Persentase responden yang menggunakan narkoba di Kota Jakarta Pusat, Jakarta Selatan, Yogyakarta, Banda Aceh, Jayapura, dan Medan, serta Kabupaten Deli Serdang dan Jayapura tahun 2015 sebesar 4,32 persen. Di antara para pengguna narkoba, persentase lebih besar ditunjukkan pada mereka dengan karakteristik pernah merokok, pernah minum minuman keras, mempunyai keluarga atau teman yang menggunakan narkoba, dan berjenis kelamin laki-laki. Pemakaian narkoba pertama kali rata-rata pada usia 18 tahun dengan alasan terbanyak ingin coba-coba. Terbukti bahwa variabel rokok, minuman keras, lingkungan, dan jenis kelamin signifikan memengaruhi penggunaan narkoba yang pertama kali. Nilai faktor percepatan untuk variabel rokok sebesar 0,3184 kali, variabel minuman keras 0,3985 kali, variabel lingkungan 0,3501 kali, dan variabel jenis kelamin 0,6773 kali.

\section{Daftar Pustaka}

Bar, A. (2007). Determinan Penyalahgunaan Narkoba pada Pekerja Pengunjung Tempat Hiburan. Kesmas: National Public Health Journal, 2(1), 3-10. https://doi.org/10.21109/kesmas.v2i1.278

[BNN] Badan Narkotika Nasional. (2009). Laporan Survei Penyalahgunaan Narkoba di Indonesia: Studi Kerugian Ekonomi dan Sosial Akibat Narkoba Tahun 2008 (p. 58). Badan Narkotika Nasional (BNN).

[BNN] Badan Narkotika Nasional. (2015). Laporan Akhir Survei Nasional Pengembangan Penyalahgunaan Narkoba Tahun Anggaran 2014 (p. 100). Badan Narkotika Nasional (BNN).

[BNN] Badan Narkotika Nasional. (2016a). Laporan Kinerja Badan Narkotika Nasional Tahun 2015 (p. 146). Badan Narkotika Nasional (BNN).

[BNN] Badan Narkotika Nasional. (2016b). Survei Prevalensi Penyalahgunaan Narkoba pada Kelompok Rumah Tangga di 20 Provinsi Tahun 2015. Badan Narkotika Nasional (BNN). 
Chen, X., Yu, B., Lasopa, S. O., \& Cottler, L. B. (2016). Current patterns of marijuana use initiation by age among US adolescents and emerging adults: Implications for intervention. The American Journal of Drug and Alcohol Abuse, 43(3), 261-270. https://doi.org/10.3109/00952990.2016.1165239

Farhadinasab, A., Allahverdipour, H., Bashirian, S., \& Mahjoub, H. (2008). Lifetime Pattern of Substance Abuse, Parental Support, Religiosity, and Locus of Control in Adolescent and Young Male Users. Iranian J. Publ Health, 37(4), 88-95.

Fergusson, D. M., Boden, J. M., \& Horwood, L. J. (2008). The Developmental Antecedents of Illicit Drug Use: Evidence from a 25-year Longitudinal Study. Drug and Alcohol Dependence, 96(1-2), 165-177. https://doi.org/10.1016/j.drugalcdep.2008.03.003

Galih, B. (2015, January). Menlu: Letak Strategis Indonesia Dimanfaatkan Pengedar Narkoba sebagai Destinasi. nasional.kompas.com. http://nasional.kompas.com/read/2015/01/21/19412251/Menlu.Letak.Strategis.Ind onesi a.Dimanfaatkan.Pengedar.Narkoba.sebagai.Destinasi

Knight, J., Roberts, T., Gabrielli, J., \& Hook, S. V. (2010). Adolescent Alcohol and Substance Use and Abuse. In Performing Preventive Services: A Bright Future Handbook. American Academy of Pediatrics.

Korhonen, T., Huizink, A. C., Dick, D. M., Pulkkinen, L., Rose, R. J., \& Kaprio, J. (2008). Role of Individual, Peer and Family Factor in the Use of Cannabis and Other Illicite Drugs: A Longitudinal Analysis among Finnish Adolescent Twins. Drug and Alcohol Dependence, 97(1-2), 33-43. https://doi.org/10.1016/j.drugalcdep.2008.03.015

Lamptey, J. J. (2005). Socio-Demographic Characteristics of Substance Abuse Admitted to a Private Specialist Clinic. Ghana Medical Journal, 39(1), 2-7. https://doi.org/10.4314/gmj.v39i1.35973

Mayet, A., Legleye, S., Falissard, B., \& Chau, N. (2012). Cannabis Use Stages as Predictors of Subsequent Initiation with Other Illicite Drugs among French Adolescent: Use of a Multi-state Model. Addictive Behaviors, 37(2), 160-166. https://doi.org/10.1016/j.addbeh.2011.09.012

Nonnemaker, J. M., Ashley, O. S., Farrelly, M. C., \& Dench, D. (2012). Parent-Child Communication and Marijuana Initiation: Evidence Using Discrete-Time Survival Analysis. Addictive Behaviors, 37(12), 1342-1348. https://doi.org/10.1016/j.addbeh.2012.07.006

Prayoga, R. (2015, January). BNN: Transaksi Narkoba Indonesia Tertinggi se-ASEAN. www.antaranews.com. bnntransaksinarkobaindonesiatertinggiseasean

[UNODC] United Nations Office on Drugs and Crime. (2016). World Drug Report 2016. United Nations.

[WHO] World Health Organization. (2015). Global Youth Tobacco Survey Indonesia Report 2014. World Health Organization. 